\title{
A case report of primary ovarian leiomyoma
}

\section{Srikala Doddareddy*, Nagashree Undinti, Vishnu Vandana G.}

Department of Obstetrics and Gynecology, Apollo Women's Hospital, Chennai, Tamil Nadu, India

Received: 11 August 2020

Accepted: 15 September 2020

\section{*Correspondence:}

Dr. Srikala Doddareddy,

E-mail: chand4191@gmail.com

Copyright: () the author(s), publisher and licensee Medip Academy. This is an open-access article distributed under the terms of the Creative Commons Attribution Non-Commercial License, which permits unrestricted non-commercial use, distribution, and reproduction in any medium, provided the original work is properly cited.

\section{ABSTRACT}

Primary ovarian Leimyoma is a rare benign mesenchymal tumour usually arising from smooth muscle of walls of ovarian blood vessels. It's mostly discovered incidentally. Here we report a case in which a 24 -year-old unmarried woman presented with pain and discomfort in lower abdomen since 10 days. On further evaluation through imaging and blood works, we proceeded with surgical management. Immunohistochemistry confirmed the final diagnosis of ovarian leiomyoma. However, it's important to keep this entity as a differential diagnosis for solid ovarian tumors.

Keywords: Abdominal mass, Ovarian leiomyoma, Pain abdomen

\section{INTRODUCTION}

Primary ovarian leimyoma is a rare benign mesenchymal tumor with an incidence of 0.5 to $1 \%$ of all benign ovarian tumours. ${ }^{1}$ It is mostly seen in age group of $20-65$ years. Literature evidence states it to be mostly unilateral and small and $80 \%$ occur in pre-menopausal women. ${ }^{2}$

The usual origin of these smooth muscle tumours includes ovarian hilar blood vessels, ovarian ligament, ovarian stromal smooth muscle cells, undifferentiated germ cells, cortical smooth muscle metaplasia. ${ }^{3}$

Ultrasound and MRI are the preferred modes of diagnosis. However, it is difficult to differentiate from mesenchymal fibrous tumors such as fibroma /fibrothecoma.

In some instances, MRI can help to determine the preoperative diagnosis but it may be impossible to differentiate precise origin of large tumour whether arising from uterus or subserous or ovary. Immunohistochemistry plays a major role in confirmatory diagnosis.

\section{CASE REPORT}

A 24yr old unmarried lady presented in obstetrics and gynecology Outpatient department with pain and discomfort in lower abdomen since 10 days. She had normal menstrual history. Her abdominal examination revealed firm mass of 20 weeks size with restricted mobility. Her biochemical, haematological parameters were all normal. All tumour markers including S. Beta $\mathrm{Hcg}$, Alpha feto protein, LDH were normal except CA 125 was marginally elevated 41 ( $<35$ is normal).

Trans abdominal ultrasound showed large abdominopelvic mass? ovarian origin/complex Right adnexal cyst? Further imaging by CT scan abdomen showed large well-defined thick irregular walled peripherally enhancing mixed solid cystic lesion arising from right adnexal region crossing midline with soft tissue thickening of adjacent part of omentum and loculated fluid-? Ovarian neoplasm. She was taken up for laparotomy with frozen section with the assistance of a surgical oncologist.

Intra operatively there was a firm, well capsulated right ovarian mass of size 20 weeks, torted thrice along with normal ovarian tissue at the base with stretching of right 
fallopian tube over the mass. After detorsion of the mass, fallopian tube gently separated with sharp and blunt dissection, partial ovariotomy done, specimen sent for frozen section. Other ovary, fallopian tube, uterus was normal. Rest of the abdomen is normal.

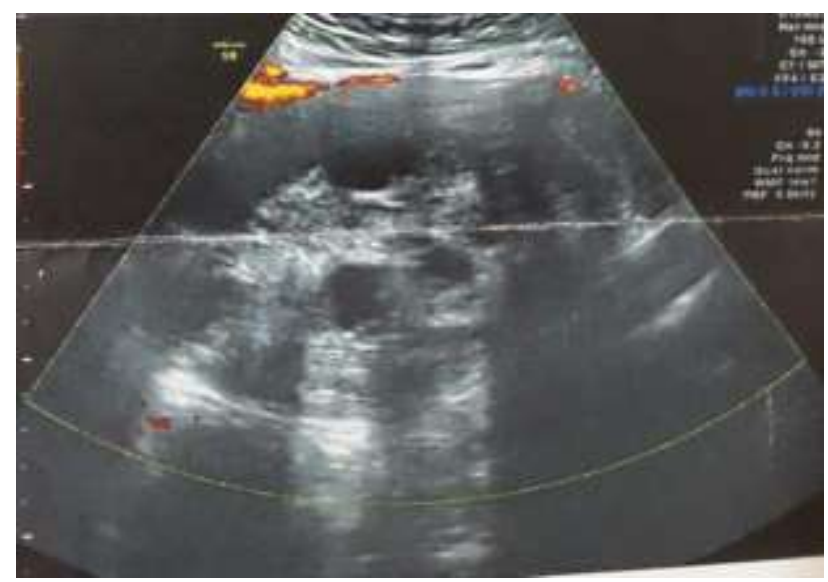

Figure 1: Trans abdominal ultrasound showed large abdomino pelvic mass.

Frozen section report came as possible spindle cell tumour of ovary and final report came as primary ovarian leiomyoma after Immunohiso-chemistry analysis. The patient had an uneventful post-operative period and was discharged after 5 days. Follow up after 6 months was normal.

Informed consent was obtained from the patient prior inclusion of details in this case report.

\section{DISCUSSION}

Primary ovarian leiomyoma is mostly reported in nulligravida which suggests estrogen has a major role to play. Most of the times ovarian leiomyoma have no symptoms and are discovered incidentally. Approximately $85 \%$ are discovered in peri and post menopause together, but $16 \%$ are seen after menopause. In symptomatic cases, it may present with abdominal pain, palpable mass, hydronephrosis due to pressure symptoms, features of Meig's syndrome and polymyositis. Ovarian leiomyoma can be most commonly misdiagnosed as pedunculated uterine leiomyoma, ovarian fibroma or even ovarian endometrioma4. Torsion could be a complication as in our case. Common Differential diagnoses are leiomyosarcoma, cystadenofbroma, sex cord stromal tumours such as fibroma/thecoma, sclerosing stromal tumour. Secondary degeneration changes like haemorrhage, calcification, hyalinisation and cyst formation can be seen.

MRI is useful adjunct to ultrasound for the purpose of diagnosing indistinct pelvic masses. ${ }^{5}$ On MRI these lesions look solid. It can be diagnosed by addressing the fact that the ovarian tissue can't be identified separately from the lesion. Post contrast evaluation with Gadolinium contrast can help to differentiate between primary ovarian lesion and fibroma/fibrothecoma in which leiomyoma shows early contrast enhancement as that of delayed and weak contrast enhancement seen in fibroma and fibrothecoma. ${ }^{6}$

To confirm the diagnosis and differentiate from other tumors; Immunohistochemical staining has to be done. The immunohistochemical staining with desmin, inhibin and alpha-smooth muscle actin are helpful. Macroscopic and microscopic features of ovarian leiomyoma are characteristic due to the presence of spindle cells and smooth muscle. These stains strong positive with Alpha smooth muscle actin and diffuse positive with desmin. They must be differentiated from leiomyosarcomas. So pathologists use criteria such as mitotic count, cytological atypia or tumor necrosis. Ki-67 is an index protein which affects growth control in leiomyoma monoclonal cells. We identify the malignant nature with its proliferation index.

A common surgical approach to ovarian lesion in middle aged to elderly patients is hysterectomy with bilateral salpingo oophorectomy. Prognosis is excellent without recurrence. Thus, fertility preserving surgeries are attempted with much success. ${ }^{4}$

\section{CONCLUSION}

Primary ovarian leiomyoma is a rare disorder and the diagnosis can be made only after histopathological and immunohistochemical evaluation. It should be kept in differential diagnosis in women presenting with solid ovarian tumors. However, Immunohistochemistry is recommended for definitive diagnosis.

Funding: No funding sources

Conflict of interest: None declared

Ethical approval: Not required

\section{REFERENCES}

1. Agrawal R, Kumar M, Agrawal L, Agrawal KK. A huge primary ovarian leiomyoma with degenerative changes-an unusual. Journal of clinical and diagnostic research: J Clinic Diagnos Resea. 2013;7(6):1152.

2. Blue NR, Felix JC, Jaque J. Primary ovarian leiomyoma in a premenarchal adolescent: first reported case. J Pediatr Adolesc Gynecol. 2014;27(4):e87-8.

3. Doss BJ, Wanek SM, Jacques SM, Qureshi F, Ramirez NC, Lawrence WD. Ovarian smooth muscle metaplasia: an uncommon and possibly underrecognized entity. Int J Gynecolo Pathol. 1999;18(1):58-62.

4. Koo YJ, Cho YJ, Kim JY, Lee JE, Kim ML, Kim $\mathrm{JM}$, et al. Ovarian leiomyoma as a potential cause of compromised fertility. Fertili Steril. 2011;95(3):1120-1. 
5. Kawano Y, Takai N, Shimano M, Nasu K, Miyakawa I. Magnetic resonance imaging findings in leiomyoma of the ovary: a case report. Archiv Gynecolo Obstet. 2006;273(5):298-300.

6. Fasih N, Prasad Shanbhogue AK, Macdonald DB, Fraser-Hill MA, Papadatos D, Kielar AZ, et al. Leiomyomas beyond the uterus: unusual locations, rare manifestations. Radiograp. 2008;28(7):1931-48.

Cite this article as: Doddareddy S, Undinti N, Vishnu VG. A case report of primary ovarian leiomyoma. Int J Reprod Contracept Obstet Gynecol. 2020;9:4313-5. 